\title{
High Beginning-of-Life Efficiency p/n InP Solar Cells
}

Richard W. Hoffman, Jr., Navid S. Fatemi, Victor G. Weizer, and Phillip P. Jenkins

Essential Research, Inc., Cleveland, OH 44135

Steven A. Ringel

The Ohio State University, Columbus, OH 43210

David A. Scheiman

NYMA Setar, Cleveland, OH 44135

David M. Wilt and David J. Brinker

National Aeronautics and Space Administration, Lewis Research Center, Cleveland, OH 44135

\section{Introduction}

It is well known that high efficiency InP solar cells have excellent radiation hardness. ${ }^{[1-3]}$ The record efficiency for InP that Keavney achieved in 1990 still stands. In fact, the $n / p$ configuration has consistently demonstrated conversion efficiency records, independent of the substrate material (see Table I). Because of a high surface recombination velocity value and the fact that no lattice matched surface passivation window layers have been identified, the design of the $n / p$ configuration cells have an extremely thin emitter region $(-30 \mathrm{~nm})$. They depend on good current collection from the base region for their high performance where the strongest wavelength conversion tends to be in the red to far red region of the spectrum, the same region which suffers the largest loss upon radiation damage due to minority carrier lifetime degradation. Even though this cell configuration has demonstrated very good radiation hardness, thick emitter $\mathrm{p} / \mathrm{n}$ diffused junction cells have demonstrated even better radiation resistance. ${ }^{[4]}$ However, the testing of the p/n configuration has been limited to cells of lower quality as judged by their beginning of life (BOL) air mass zero (AM0) efficiency values typically below $15 \%$. The emitter structures in these cells, which must be thick relative to emitters in the $n / p$ configuration for sheet resistance considerations, have been ineffective and therefore, the $\mathrm{p} / \mathrm{n}$ configuration cells have suffered from poor blue response, low short circuit current density $\left(J_{S C}\right)$ and moderate efficiencies. ${ }^{[5,6]}$

Table I - Highest reported AMO efficiencies for InP cells on various substrates.

\begin{tabular}{|l|c|c|c|}
\hline Substrate & Configuration & Efficiency, (\%) & Source \\
\hline InP & $\mathbf{n} / \mathbf{p}$ & 19.1 & Spire Corp. $^{[7]}$ \\
InP & $\mathrm{p} / \mathrm{n}$ & 15.9 & Arizona State $^{[8]}$ \\
$\mathrm{GaAs}$ & $\mathrm{n} / \mathrm{p}$ & 13.7 & NREL $^{[9]}$ \\
$\mathrm{Si}$ & $\mathrm{n} / \mathrm{p}$ & 13.0 & Spire Corp. $^{[10]}$ \\
\hline
\end{tabular}

We recently reported on $\mathrm{p} / \mathrm{n}$ InP cells which had AM0 efficiencies above $16 \% .^{[11]}$ These cells were fabricated using a new Ag-Zn front contact system ${ }^{[12]}$ which eliminated the necessity of an InGaAs $\mathrm{p}$-type contact layer employed in early $\mathrm{p} / \mathrm{n}$ epitaxial InP cells. Diffusion of $\mathrm{Zn}$ during the time it takes to grow the InGaAs layer caused the loss of junction depth control in these early cells. ${ }^{[13]}$

- The Ag-Zn metallurgy allowed ohmic contact formation to the p-type InP without degrading junctions as thin as $100 \mathrm{~nm}$. It was believed that cells fabricated without the InGaAs layer would have better junction depth control, since less opportunity for $\mathrm{Zn}$ diffusion existed, and therefore higher conversion performance was expected. 
InP structures were grown by organo-metallic vapor phase epitaxy (OMVPE) under typical low pressure conditions. We used $\mathrm{PH}_{3}, \mathrm{AsH}_{3}, \mathrm{SiH}_{4}$, trimethylgallium, trymethylindium, diethylzinc and hydrogen in our home-built reactor. InP and InGaAs layers were grown at $620^{\circ} \mathrm{C}$, a total pressure of 150 torr and a V/III ratio of 100 . Standard reverse photolithography and vacuum resistive evaporation techniques were used to form the contacts. A dual layer anti-reflection coating (ARC) consisting of $\mathrm{MgF}_{2} / \mathrm{ZnS}$ and optimized for the $\mathrm{AM} 0$ spectrum was also deposited by vacuum resistive evaporation. Cell with areas of $0.36 \mathrm{~cm}^{2}$ and $1.0 \mathrm{~cm}^{2}$ were fabricated on the same wafer, defined by mesa etching and had grid shadowing of $6 \%$ and $5 \%$ respectively. Cell performance was measured after various steps of processing.

\section{Results and Discussion}

We fabricated $\mathrm{p} / \mathrm{n}$ InP cells with efficiencies exceeding $17.6 \%$ under AM0, one sun, $25^{\circ} \mathrm{C}$ test conditions. A summary of the cell performance data is presented in Table II. Many cells had efficiency values above $17 \%$. A peak cell efficiency of $17.64 \%$ was obtained from a $0.36 \mathrm{~cm}^{2}$ area cell. The corresponding I-V curve for this cell is shown in Figure 2. We were also able to achieve nearly the same performance from cells which were $1.0 \mathrm{~cm}^{2}$ in area as demonstrated by the I-V curve in Figure 3.

Table II - Results of p/n InP solar cells tested under AMO, one sun, $25^{\circ} \mathrm{C}$ at NASA LeRC.

\begin{tabular}{|l|c|c|c|c|c|}
\hline Cell & $\begin{array}{c}\mathrm{J}_{\mathrm{SC}} \\
\left(\mathrm{mA} / \mathrm{cm}^{2}\right)\end{array}$ & $\begin{array}{c}\mathrm{V}_{\mathrm{OC}} \\
(\mathrm{mV})\end{array}$ & $\begin{array}{c}\mathrm{FF} \\
(\%)\end{array}$ & $\begin{array}{c}\text { Efficiency } \\
(\%)\end{array}$ & $\begin{array}{c}\text { Area } \\
\left(\mathrm{cm}^{2}\right)\end{array}$ \\
\hline $393-1 \mathrm{~A}$ & 34.9 & 854 & 79.2 & 17.3 & 1.0 \\
$393-1 \mathrm{C}$ & 35.2 & 850 & 77.5 & 17.0 & 1.0 \\
$393-2 \mathrm{C}$ & 35.8 & 854 & 77.9 & 17.4 & 1.0 \\
$393-3 \mathrm{~A}$ & 35.2 & 855 & 79.7 & 17.5 & 1.0 \\
$393-3 \mathrm{C}$ & 35.0 & 855 & 79.9 & 17.5 & 1.0 \\
$393-3 \mathrm{D}$ & 34.8 & 854 & 81.1 & 17.6 & 0.36 \\
\hline
\end{tabular}

In Figure 4 we show a comparison of the external quantum efficiency of our $\mathrm{p} / \mathrm{n}$ cell to the external quantum efficiency measured from the previous record $\mathrm{p} / \mathrm{n}$ cell from the literature. Our $\mathrm{p} / \mathrm{n}$ InP cells have excellent blue response, significantly higher than the blue response of the previous record $\mathrm{p} / \mathrm{n}$ cell while maintaining approximately equivalent red response. In Figure 5 is a comparison of the external quantum efficiency of our $\mathrm{p} / \mathrm{n}$ InP cell to the internal quantum efficiency of the record $\mathrm{n} / \mathrm{p}$ cell. Our $\mathrm{p} / \mathrm{n}$ cell has a significantly higher blue response, even though the emitter region of the $\mathrm{p} / \mathrm{n}$ cell is almost an order of magnitude thicker than the emitter region used in the record $\mathrm{n} / \mathrm{p}$ cell. We do, however, observe a significantly lower red response for the $\mathrm{p} / \mathrm{n}$ cell compared to the record $\mathrm{n} / \mathrm{p}$ cell, a result of lower minority carrier diffusion length in the $n$-type base than the p-type base. However, it was precisely in this wavelength region where the $n / p$ cell lost current collection when exposed to radiation due to the reduction of minority carrier diffusion length in the base. The $\mathrm{p} / \mathrm{n}$ cells of the present work may provide better radiation resistance since they depend less strongly on the long wavelength current collection for high device performance. 
Even though cells fabricated with $\mathrm{Ag}-\mathrm{Zn}$ contacts exhibited an AM0 conversion efficiency above $16 \%$, they suffered from other anomalous behavior. Interesting aging effects were observed where the cells improved with age, mostly through improvement to $\mathrm{J}_{\mathrm{SC}}$ values. In addition, a reversible photo-degradation was observed where the $\mathrm{J}_{\mathrm{SC}}$ value decreased $6 \%$ per hour upon exposure to the AM0, one-sun light in a X-25 solar simulator. We did, however, report an encouraging result from these cells, in that they demonstrated the possibility of very good quantum efficiency in the blue region of the light spectrum as compared to the $\mathrm{n} / \mathrm{p}$ configuration.

In the present work, we report on the fabrication of high performance $\mathrm{p} / \mathrm{n}$ InP solar cells, which directly resulted from improved growth of p-type InP. Through our understanding of the mechanisms involved in $\mathrm{Zn}$ doping of InP, we have gained better control of the OMVPE growth process, and have achieved record efficiencies for $\mathrm{p} / \mathrm{n}$ InP solar cells under AM0, $25^{\circ} \mathrm{C}$ test conditions. These cells exhibit excellent blue response and are believed to demonstrate improved radiation resistance compared to $\mathrm{n} / \mathrm{p}$ InP cells.

\section{Experiment}

We have returned to the conventional $\mathrm{p} / \mathrm{n}$ InP cell design seen in Figure 1 where we used p-type InGaAs lattice matched to InP under the Au-Ge front contact grid fingers. In previous work ${ }^{[11]}$ we reported significant p-type dopant passivation due to conditions under which the samples were cooled to room temperature after growth. Under normal OMVPE growth, the samples are cooled to room temperature, or at least to $300-400^{\circ} \mathrm{C}$ in a partial pressure of appropriate hydride gas $\left(\mathrm{PH}_{3}\right.$ for phosphides, $\mathrm{AsH}_{3}$ for arsenides). The unexpected passivation resulted from the rapid, deep diffusion of atomic hydrogen, available from the cracking of hydride gasses or organo-metallic vapors, which formed a complex with substitutional, active $\mathrm{Zn}$, thus deactivating $\mathrm{p}$-type majority carriers. To avoid this passivation effect, the $\mathrm{p} / \mathrm{n}$ InP junctions were cooled from the growth temperature flowing only $\mathrm{H}_{2}$ through the reactor, however, In droplets appeared on the InP surface due to loss of phosphorus. To prevent the surface decomposition during cool-down, we deposited lattice matched InGaAs on the InP cell structure and then cooled the structures under $\mathrm{H}_{2}$. We then removed the In $\mathrm{GaAs}$ between the fingers after front contact formation, thus protecting the InP surface throughout cell processing.

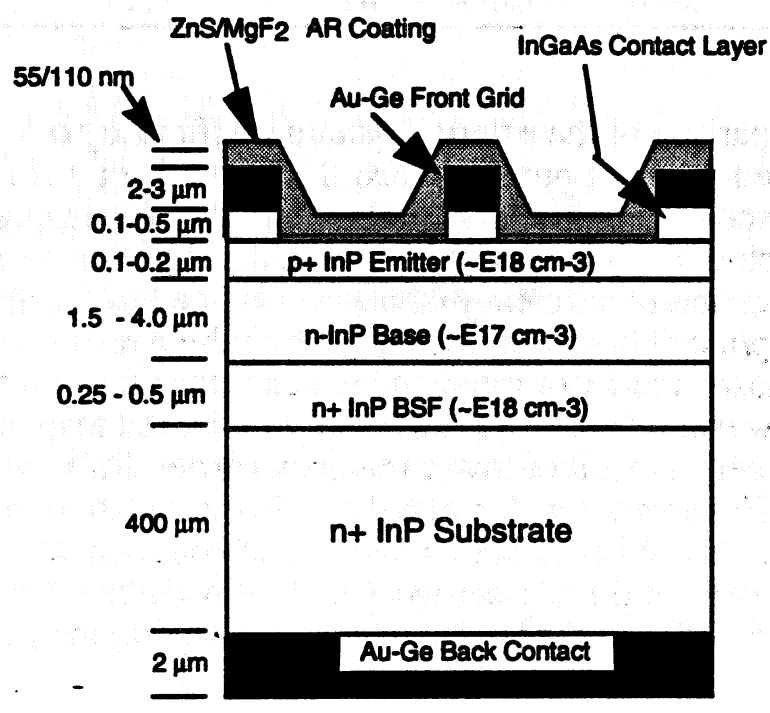

Figure 1 - Conventional p/n InP solar cell design employing InGaAs p-type contact layer under grid fingers. 


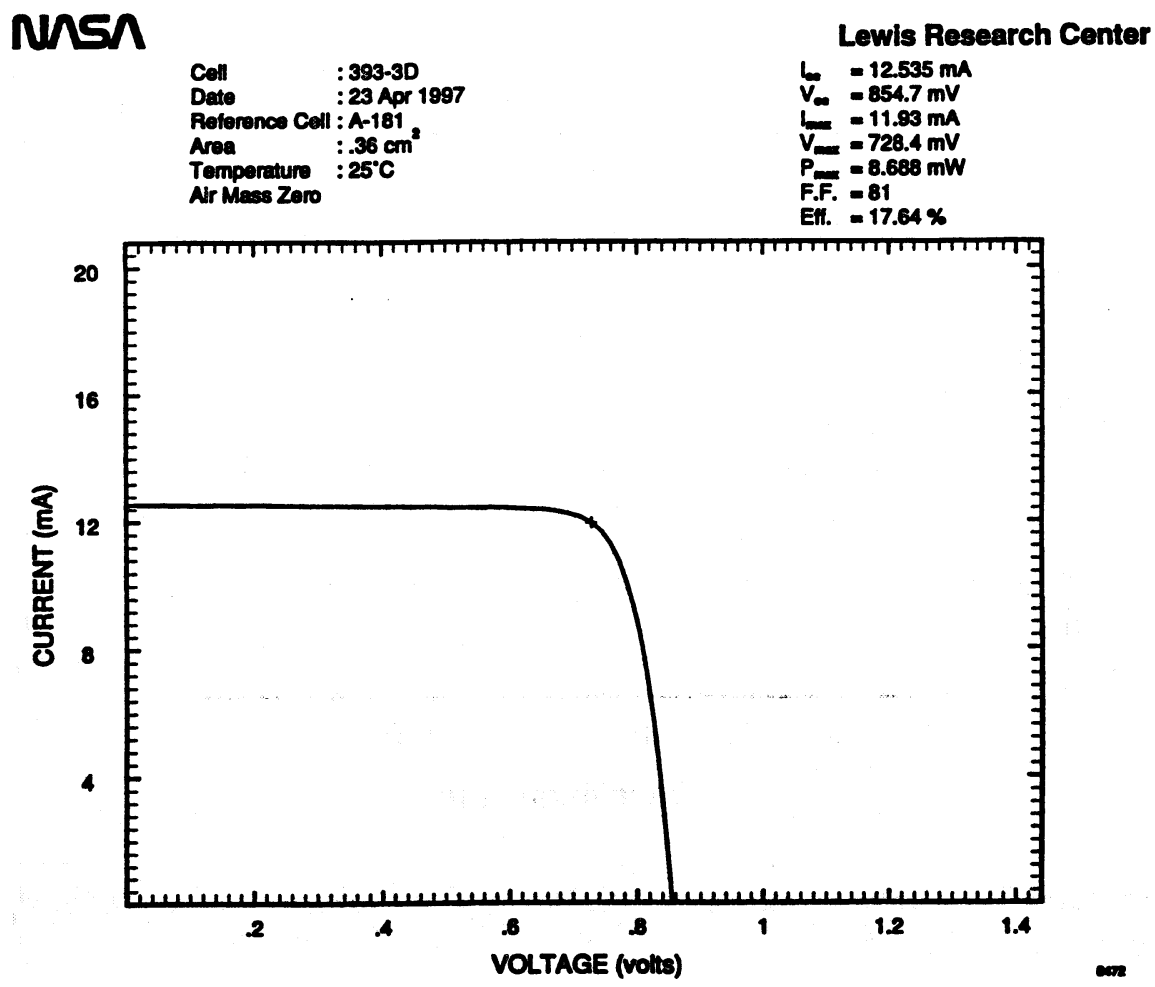

Figure 2 - I-V curve from the highest performance p/n InP cell, $\left(0.36 \mathrm{~cm}^{2}\right.$ area) taken under AMO, $25^{\circ} \mathrm{C}$, one-sun conditions.

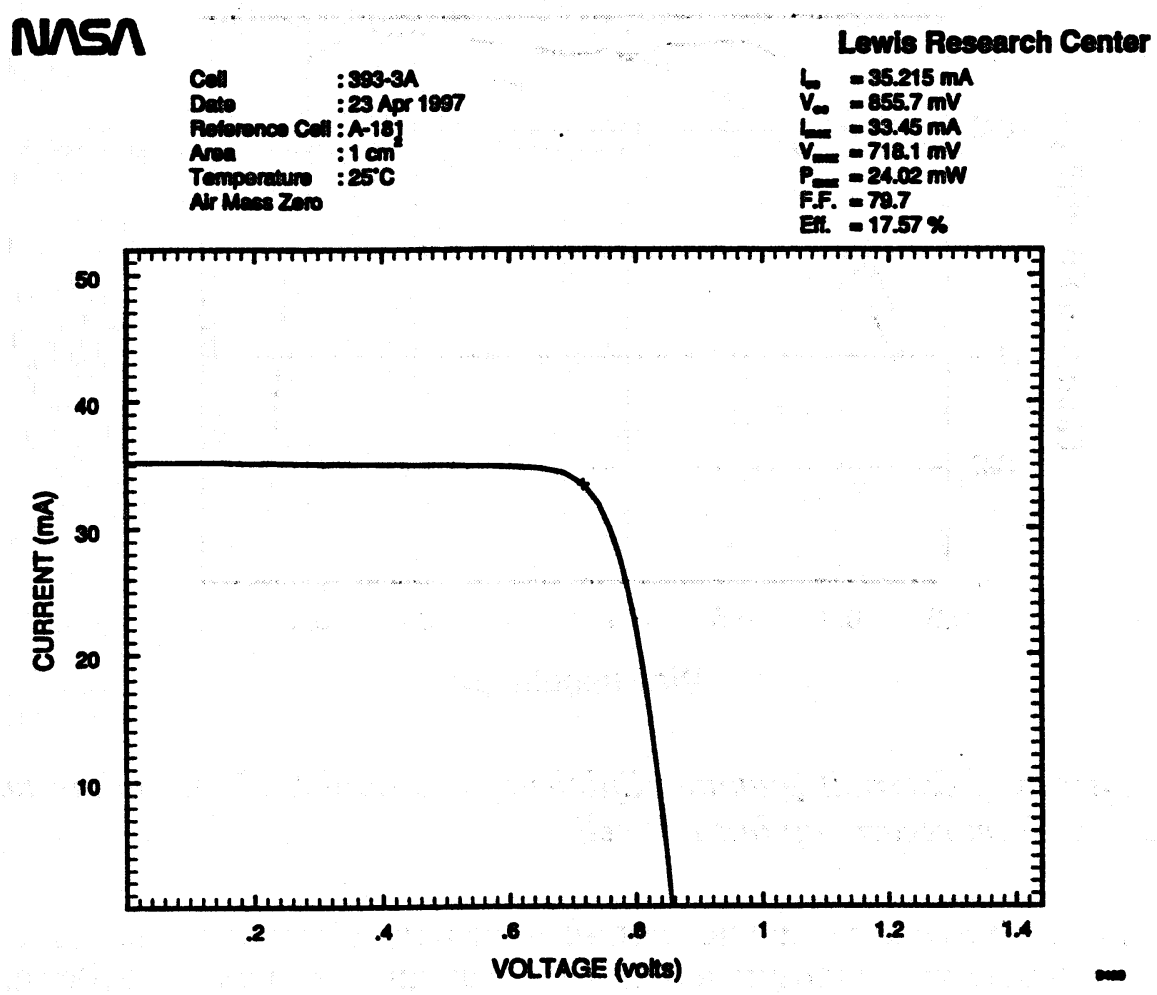

Figure $3-I-V$ curve from the best $1.0 \mathrm{~cm}^{2}$ area, p/n InP solar cell under $A M 0,25^{\circ} \mathrm{C}$, one-sun conditions. 


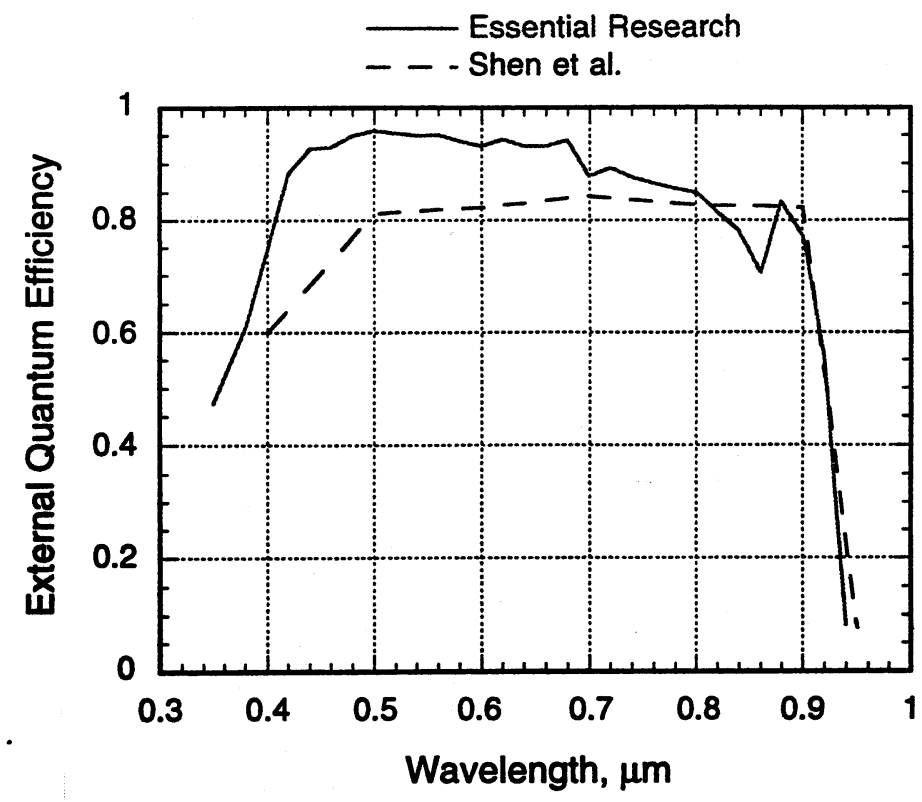

Figure 4 - Comparison on external quantum efficiency of our p/n InP cell to the previous record pln cell.

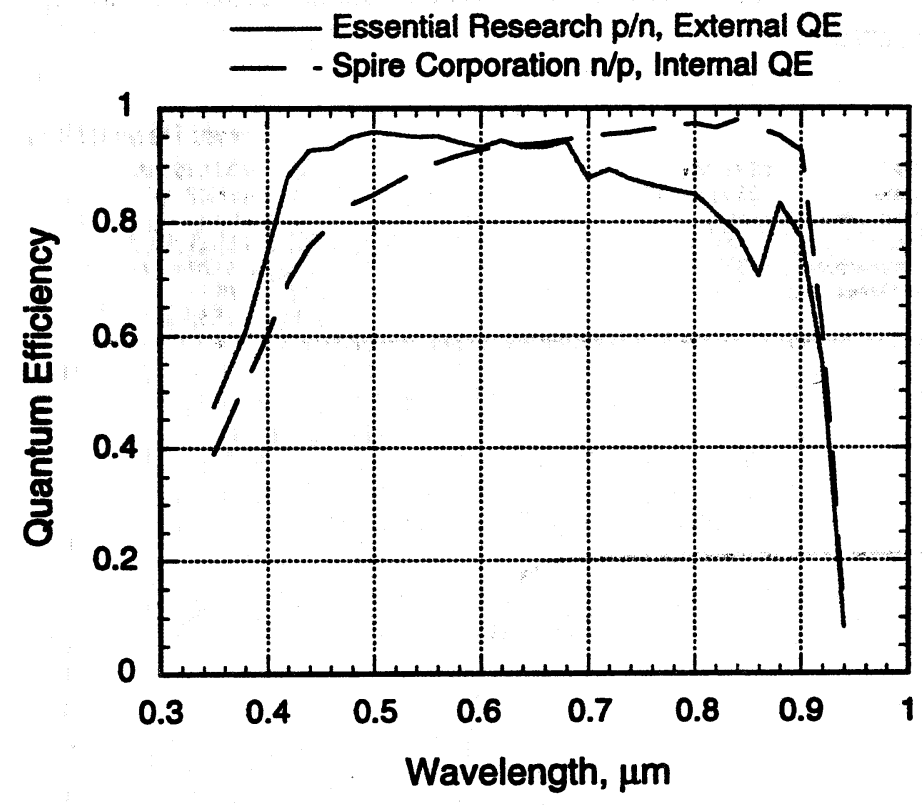

Figure 5 - Comparison of External Quantum Efficiency of $p / n \operatorname{InP/InP}$ cell to internal quantum efficiency from record $n / p$ InP/nP cell.

Our previous $\mathrm{p} / \mathrm{n}$ cells showed a reversible photo-degradation effect where the $\mathrm{J}_{\mathrm{sc}}$ value was reduced by $6 \%$ per hour during exposure to AM0, one-sun intensity light. ${ }^{[1]}$ After removal from the solar simulator and resting in laboratory environment for a period of several days, the cells recovered to their pre-exposed performance level. We subjected cells from our present work to a 
one hour AMO light soak and did not observe any significant change in measured cell performance. An example of the light soaking results (on a cell without ARC) are seen in Table III.

Table III - Stability of p/n InP cells under light soaking in AMO, one-sun conditions at $25^{\circ} \mathrm{C}$.

\begin{tabular}{|c|c|c|c|c|}
\hline $\begin{array}{c}\text { Soak Time } \\
(\mathrm{min} .)\end{array}$ & $\begin{array}{c}\mathrm{J}_{\mathrm{SC}} \\
\left(\mathrm{mA} / \mathrm{cm}^{2}\right)\end{array}$ & $\begin{array}{c}\mathrm{V}_{\mathrm{OC}} \\
(\mathrm{mV})\end{array}$ & $\begin{array}{c}\mathrm{FF} \\
(\%)\end{array}$ & $\begin{array}{c}\text { Efficiency } \\
(\%)\end{array}$ \\
\hline 0 & 25.2 & 854 & 79.5 & 12.5 \\
60 & 25.0 & 853 & 79.7 & 12.4 \\
\hline
\end{tabular}

Carrier passivation is a common occurrence in semiconductors when specifically introduced for defect passivation ${ }^{[14]}$, however, it was an unexpected observation in our OMVPE grown p-type InP . As an example of the significance of the effect, we designed an experiment where four identical samples of $\mathrm{Zn}$ doped InP were grown by OMVPE. Each sample was $2 \mu \mathrm{m}$ thick and differed only by the gas composition exposure during cooling from the $620^{\circ} \mathrm{C}$ growth temperature to $300^{\circ} \mathrm{C}$. One sample was cooled only in hydrogen, one was cooled in a mixture of hydrogen and phosphine, another in diethylzinc and hydrogen and the last sample was cooled in phosphine, diethylzinc and hydrogen. Below $300^{\circ} \mathrm{C}$ all samples were cooled in hydrogen. Carrier concentration depth profiles were measured using a Poloran $\$ C-V$ instrument. The C-V measurement of carrier concentration measures the active net dopant concentration. The results of profiling are shown in Figure 6. In the figure, the carrier concentration of the sample cooled in hydrogen is relatively flat for over $1 \mu \mathrm{m}$ depth. The value of carrier concentration was nearly identical to the concentration of $\mathrm{Zn}$ as determined by SIMS measurement on other similarly doped samples. The samples cooled in the phosphine mixture and in the diethylzinc mixture both show similar reduction of carriers from $4 \times 10^{18}$ carriers $/ \mathrm{cm}^{3}$ to $1.5 \times 10^{18}$ carriers $/ \mathrm{cm}^{3}$ due to hydrogen uptake. The phosphine cooled sample was affected slightly stronger than the diethylzinc exposed sample. Both phosphine and diethylzinc liberate atomic hydrogen when decomposed at elevated temperature. The sample cooled in the mixture of phosphine, diethylzinc and hydrogen showed a very large passivation effect, roughly an order of magnitude reduction of carrier concentration at the surface which also extends well into the InP layer. The additional passivation observed in this sample was explained by the fact that small amounts of organo-metallic compounds can enhance the cracking of hydride gasses ${ }^{[15]}$, thus liberating a higher concentration of atomic hydrogen. The evidence for diffusion of hydrogen is seen most easily in this sample by the increase in carrier concentration with depth (straight line on a logarithmic plot).

The improvement in observed cell performance of the $\mathrm{p} / \mathrm{n}$ InP cells resulted from a full understanding of the OMVPE growth of $\mathrm{Zn}$ doped p-type InP and, therefore, better control of the p-type InP properties. The p-type carrier passivation effects are directly related to the previously observed aging and light soaking performance anomalies. The effect of carrier passivation on cell performance is further demonstrated in Figure 7. In this figure we compare I-V curves from two cells which have identical structures. They differ only in the method used to cool the structures from the OMVPE growth temperature. Both samples were capped with InGaAs prior to cooling. One structure, labeled $\mathrm{AsH}_{3}+\mathrm{H}_{2}$ on the figure, was cooled to $300^{\circ} \mathrm{C}$ while a mixture of 0.7 torr partial pressure arsine and hydrogen flowed through the reactor. Below $300^{\circ} \mathrm{C}$ this sample was cooled in hydrogen to room temperature. The other structure, labeled $\mathrm{H}_{2}$, was cooled with only hydrogen flowing in the reactor. The effect of the resulting carrier passivation due to trapped hydrogen during cooling was evidenced by a comparison of the performance results. The $\mathrm{J}_{\mathrm{SC}}$ values were not affected by the carrier passivation in the emitter, which means that the minority carrier lifetime was already sufficiently large in the p-type emitter so that reducing the emitter doping, thus increasing minority carrier lifetime, did not change the carrier collection. It did, 
however, significantly affect the $V_{o c}$ and $F F$ values, which can be understood by the following. A reduction in the emitter doping normally entails a drop in $\mathrm{V}_{\mathrm{OC}}$, and in turn, a decrease in $\mathrm{FF}$. $A$ further decrease in FF can also occur because of the increase in the emitter sheet resistance due to a reduction in the emitter doping.

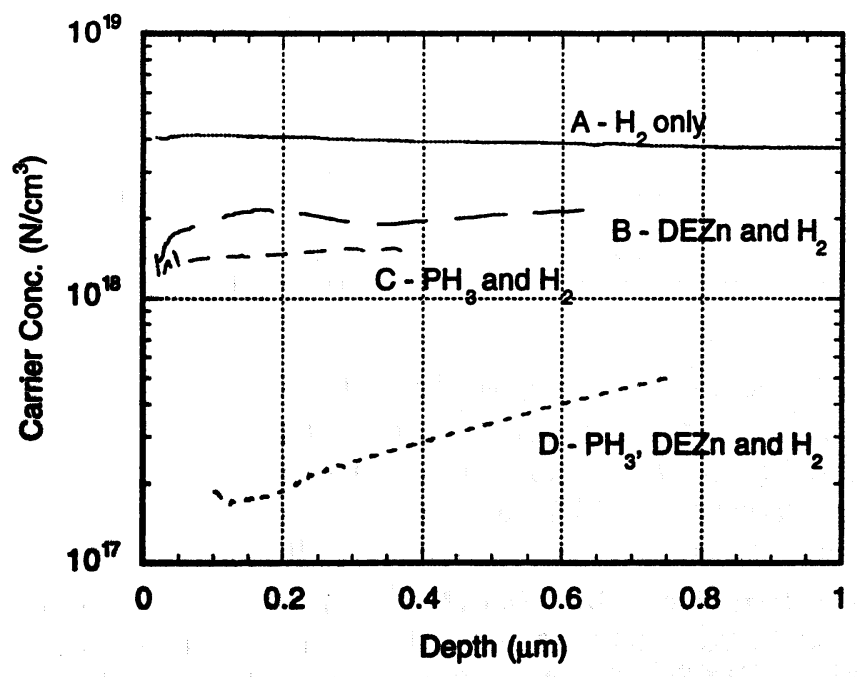

Figure 6 - Carrier passivation as a function of sample cooling conditions from OMVPE growth temperature ${ }^{[1]}$. Curve $A$ cooled in hydrogen, $B$ in diethylzinc and hydrogen, $C$ in phosphine and hydrogen, and $D$ in phosphine, diethylzinc and hydrogen.

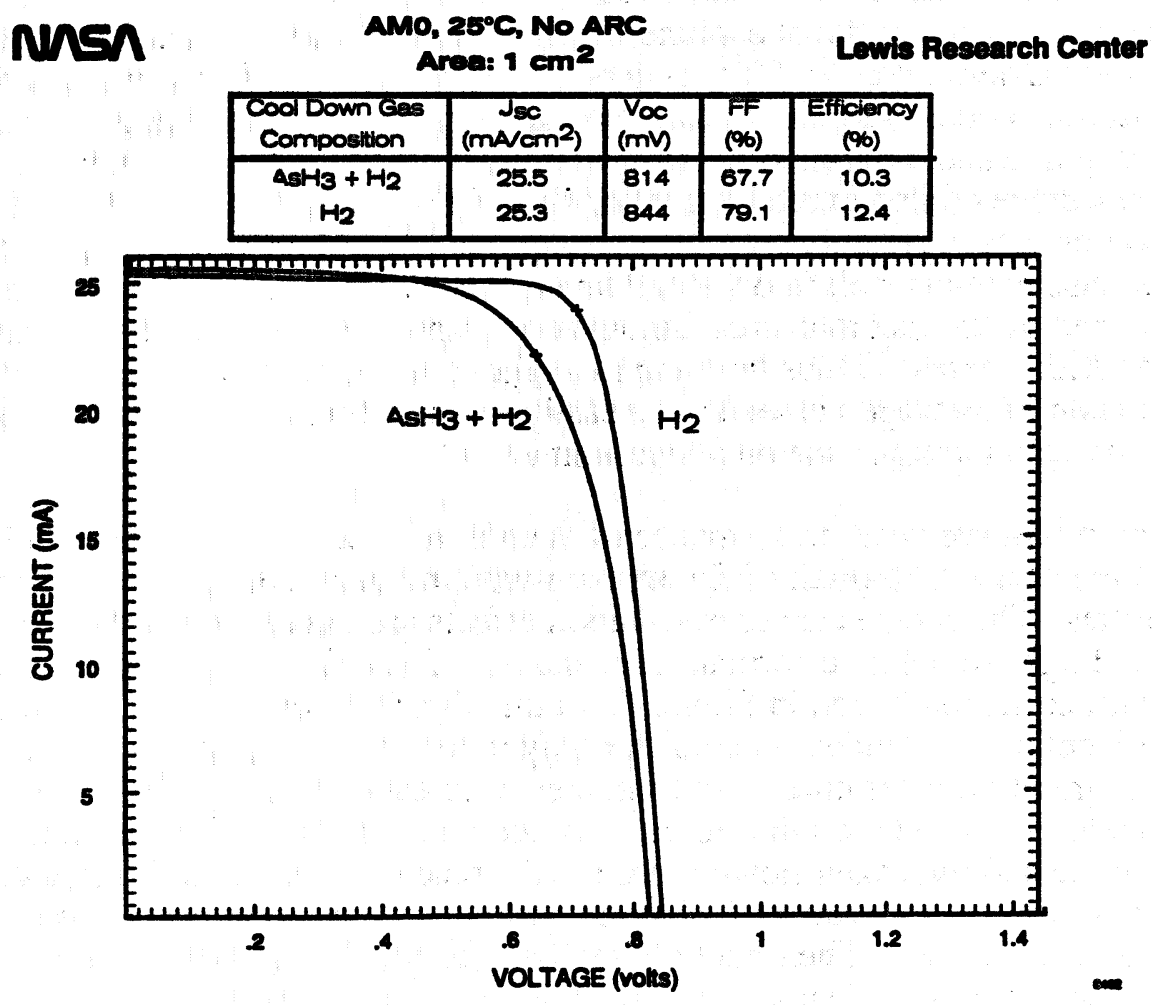

Figure 7 - Demonstration of the carrier passivation effect due to cooling gas composition in $p$-type InP on p/n solar cell performance. 
We believe that the conversion efficiency of the p/n cells can readily be improved to the mid $18 \%$ level. Efficiencies as high as $19 \%$ may also be achievable. Further, it is believed that these high efficiency $\mathrm{p} / \mathrm{n}$ cells will not suffer as much performance loss due to radiation exposure as the $\mathrm{n} / \mathrm{p}$ configuration cells since a majority of the current from the $\mathrm{p} / \mathrm{n}$ cells now originates from the blue response of the emitter region, whereas the largest loss in performance of the $n / p$ cells due to radiation damage occurs in the collection of long wavelength light. This loss is due to the reduction of the minority carrier diffusion length in the base of the $\mathrm{n} / \mathrm{p}$ cell.

\section{Conclusions}

We have achieved a new record efficiency of $17.6 \%$, (AM0) for a p/n InP homo-epitaxy solar cell. In addition, we have eliminated a previously observed photo-degradation of cell performance, which was due to losses in $\mathrm{J}_{\mathrm{sc}}$. Cells soaked in AM0 spectrum at one-sun intensity for an hour showed no significant change in cell performance. We have discovered carrier passivation effects when using $\mathrm{Zn}$ as the p-type dopant in the OMVPE growth of InP and have found a method to avoid the unexpected effects which result from typical operation of OMVPE cell growth.

This work was supported by the NASA Lewis Research Center under the SBIR contract NAS3-27677. George Rybicki is the technical monitor of this contract.

\section{References}

[1] A. Yamamoto, M. Yamaguchi and C. Uemura, Appl. Phys. Lett., 44 (1984) 611.

[2] I. Weinberg, C.K. Swartz, and R.E. Hart Proc. of the $18^{\text {th }}$ IEEE Photovoltaic Specialist Conference p.1722 (1985).

[3] R.J. Walters, S.R. Messenger, G.P. Summers, E.A. Burke and C.J. Keavney, Proc. of the $22^{\text {nd }}$ IEEE Photovoltaic Specialist Conference p.1560 (1991).

[4] M. Faur, M. Faur, DJ. Flood, I Weinberg, C. Goradia, M. Goradia and C. Vargas-Aburto, Proc. of the $23^{\text {rd }}$ IEEE Photovoltaic Specialist Conference p.1437 (1993).

[5] P.R. Sharps, M.L. Timmons, S.R. Messenger, H.L. Cotal, G.P. Summers and P.A. Illes, Proc. of the $25^{\text {th }}$ Photovoltaic Specialist Conference p.175 (1996).

[6] H. Cotal, S.R. Messenger, R.J. Walters and G.P. Summers, Proc. of the $25^{\text {th }}$ Photovoltaic Specialist Conference p.219 (1996).

[7] C.J. Keavney, V.E. Haven, and S.M. Vemon, Proc. of the $21^{\text {st }}$ IEEE Photovoltaic Specialist Conference p. 141 (1990).

[8] K.Y. Choi, C.C. Shen and B.I. Miller, Proc. of the $19^{\text {th }}$ IEEE Photovoltaic Specialists Conference p. 255 (1987).

[9] M.W. Wanlass, T.J. Coutts, J.S. Ward and K.A. Emery, Proc. of the $22^{\text {nd }}$ Photovoltaic Specialist Conference p.159 (1991).

[10] S.J. Wojtczuk, N.H. Karam, P. Gouker, P. Colter, S.M. Vernon, G.P. Summers, R.J. Walters and R.Statler, $1^{\text {st }}$ World Conference on Photovoltaic Energy Conversion p. 1705 (1994).

[11] R.W. Hoffman, Jr., N.S. Fatemi, P. Jenkins, D.A. Scheiman, S.A. Ringel, W.C. Davis, V.G. Weizer, D.M. Wilt and D.J. Brinker, Proc. of the $25^{\text {th }}$ Photovoltaic Specialist Conference p.171 (1996).

[12] N.S. Fatemi, V.G. Weizer, D.M. Wilt and R.W. Hoffman Jr., Proc. of the $1^{\text {st }}$ World Conference on Photovoltaic Energy Conversion p.2129 (1994).

[13] S.J. Wojtczuk, N.H. Karam, P. Gouker, P. Colter, S.M. Vernon, G.P. Summers, R.J. Walters and R. Statler, Proc of the $1^{\text {st }}$ World Conference on Photovoltaic Energy Conversion p.1705 (1994).

[14] For example see S.A.Ringel and B. Chatterjee, "Hydrogenation of Compound Semiconductors," in Topics in Applied Vacuum Science \& Technology, ed. by S.J.Pearton (Research Signpost Publications, India, 1997).

[15] N. Buchan, C.A. Larsen and G. B. Stringfellow, Appl. Phys. Lett. 51 (1987) 1024. 